\title{
Pediatric High Grade Gliomas in the Context of Cancer Predisposition Syndromes
}

\author{
Orli Michaeli, M.D., Uri Tabori, M.D. \\ Division of Hematology/Oncology, The Hospital for Sick Children, University of Toronto, Toronto, Canada
}

Germline mutations in cancer causing genes result in high risk of developing cancer throughout life. These cancer predisposition syndromes (CPS) are especially prevalent in childhood brain tumors and impact both the patient's and other family members' survival. Knowledge of specific CPS may alter the management of the cancer, offer novel targeted therapies which may improve survival for these patients, and enables early detection of other malignancies. This review focuses on the role of CPS in pediatric high grade gliomas (PHGG), the deadliest group of childhood brain tumors. Genetic aspects and clinical features are depicted, allowing clinicians to identify and diagnose these syndromes. Challenges in the management of PHGG in the context of each CPS and the promise of innovative options of treatment and surveillance guidelines are discussed with the hope of improving outcome for individuals with these devastating syndromes.

Key Words : Cancer predisposition syndrome - High grade glioma - Li fraumeni syndrome - Constitutional mismatch repair deficiency . Neurofibromatosis $1 \cdot$ Surveillance.

\section{INTRODUCTION}

Brain tumors are the most common solid tumors during childhood. In adults, mutations which are observed in most tumors are caused by external insults ${ }^{115}$. In contrast, a large subset of mutations in pediatric brain tumors will originate in the germline as part of cancer predisposition syndrome (CPS). According to Knudson's "two hit” hypothesis, the germline mutation results in a first hit, allowing for a higher chance of a single somatic "second" hit to cause cancer. While this model may not explain the genetic etiology of all heritable cancers, it has been a guiding principle for cancer susceptibility and pathogenesis $^{17}$.
At least $10 \%$ of children with cancer are primarily affected by a $\mathrm{CPS}^{76,80,115)}$. However, newer estimates are much higher ${ }^{17,56)}$. Recognition of a CPS is crucial for patients and their family members. Specific germline mutations confer different risk for tumor response and survival as well as offer mutational derived therapies. Moreover, once discovered, surveying patients with CPS enables early detection and has proven to improve survival $^{86,109)}$.

Specific brain tumor types are associated with higher prevalence of germline mutations. Atypical teratoid/rhabdoid tumors during early childhood carries up to $35 \%$ risk of belonging to the Rhabdoid predisposition syndrome, caused by germline SMRCB1 or rarely SMARCA4 mutations ${ }^{26)}$. On the

- Received : February 8, 2018 •Revised : March 8, 2018 •Accepted : March 8, 2018

- Address for reprints : Uri Tabori, M.D.

Division of Hematology/Oncology, The Hospital for Sick Children, University of Toronto, 555 University Avenue, Toronto ON M5G1X8, Canada Tel : +1-416-813-7654, Fax : +1-416-813-5024, E-mail : uri.tabori@sickkids.ca

This is an Open Access article distributed under the terms of the Creative Commons Attribution Non-Commercial License (http://creativecommons.org/licenses/by-nc/4.0) which permits unrestricted non-commercial use, distribution, and reproduction in any medium, provided the original work is properly cited. 
other hand, each CPS has a unique group of brain tumors which are specific to the germline mutation. For example, patients with Gorlin syndrome harbor an increased risk for early onset sonic hedgehog medulloblastoma $\left(\mathrm{MB}_{\mathrm{SH}}\right)$. These $\mathrm{MB}_{\mathrm{SHH}}$ confer better survival than other medulloblastoma at this age.

Pediatric high grade gliomas (PHGG) are the deadliest group of childhood brain tumors. In this review, we will focus on PHGG and describe three of the more prominent syndromes in these cancers-Li Fraumeni syndrome (LFS), constitutional mismatch repair deficiency and neurofibromatosis 1 . Table 1 summarizes the major features of those three CPS.

\section{FRAUMENI SYNDROME}

LFS is an autosomal dominant CPS and one of the hallmarks of such syndromes in children and adults. LFS is characterized by high frequency of malignancies in multiple organs and lack of other clinical features ${ }^{71}$. Estimates of prevalence are 1 in 5000-20000 individuals ${ }^{34,59)}$, though recently it was suggested to be an underestimation ${ }^{4)}$.

LFS has classical clinical criteria (Table 2). However, following the identification of germline mutations in the TP53 as the syndrome's etiology ${ }^{71)}$, more cases that were not fitting the classical LFS criteria were found ${ }^{34,110}$. Hence, the clinical criteria have been revised several times, to the recent more comprehensive "revised Chompret criteria"16,104). These criteria are therefore merely a guidance for individuals who should be referred for a genetic diagnosis, though not all of the families fitting the clinical criteria harbor detectable germline p53 mutations $^{34,69,70,78)}$.

\section{Cancer spectrum}

The penetrance of cancer is high, yet it is highly variable. The lifetime risk of developing at least one cancer is approximately $75 \%$ in men and $93-100 \%$ in women, and up to $41 \%$ of children will have cancer by age 18 years ${ }^{16}$.

The cancer spectrum is vast and includes sarcomas, premenopausal breast cancer, adrenocortical carcinoma (ACC), brain tumors, hematologic malignancies and others. Brain tumors are the second most common malignancies in children with LFS following ACC, as $26 \%$ of childhood tumors are in the central nervous system (CNS), while only $13 \%$ of adult tumors in LFS are in this location ${ }^{16,67)}$. The median age of onset of brain tumors in LFS is 16 years ${ }^{78}$, compared to 57 years in the general population.

Table 1. Major features of selected cancer predisposition syndromes associated with PHGG*

\begin{tabular}{|c|c|c|c|c|}
\hline Syndrome & History & Physical exam & Other neoplasms & Treatment implications \\
\hline LFS & $\begin{array}{l}\text { Multiple cases of cancer } \\
\text { in the family }\end{array}$ & No specific features & $\begin{array}{l}\text { Sarcomas } \\
\text { Premenopausal breast cancer } \\
\text { Adrenocortical carcinoma } \\
\text { Choroid plexus carcinoma } \\
\text { MB }_{\text {SHH }} \\
\text { Hematologic malignancies } \\
\text { Others }\end{array}$ & $\begin{array}{l}\text { Probable increased risk of } \\
\text { second malignancies in } \\
\text { the radiation field }\end{array}$ \\
\hline CMMRD & $\begin{array}{l}\text { Consanguinity } \\
\text { Lynch syndrome in the family } \\
\text { Sibling with childhood cancer } \\
\text { Multiple cancers }\end{array}$ & $\begin{array}{l}\text { Café-au-lait macules } \\
\text { Refer to table } 4 \text { for additional features }\end{array}$ & $\begin{array}{l}\text { T lymphoblastic lymphoma } \\
\text { Colorectal carcinoma/ adenoma } \\
\text { Others }\end{array}$ & $\begin{array}{l}\text { Resistance to temozolomide } \\
\text { and some alkylators } \\
\text { Potential therapeutic effect } \\
\text { of immune checkpoint } \\
\text { inhibitors for hypermutant } \\
\text { tumors }\end{array}$ \\
\hline NF-1 & $\begin{array}{l}\text { First-degree relative with NF1 } \\
\text { Learning disabilities and other } \\
\text { neurocognitive deficits }\end{array}$ & $\begin{array}{l}\text { Café-au-lait macules } \\
\text { Neurofibromas (cutaneous and } \\
\text { plexiform) } \\
\text { Freckling (axillary/ inguinal) } \\
\text { Lisch nodules } \\
\text { Refer to text for additional features }\end{array}$ & $\begin{array}{l}\text { Optic glioma and other LGG } \\
\text { MPNST } \\
\text { Rhabdomyosarcoma } \\
\text { JMML and other leukemias } \\
\text { Others }\end{array}$ & $\begin{array}{l}\text { HGG- same as sporadic } \\
\text { LGG- observation when } \\
\text { appropriate increased } \\
\text { radiation related A/E } \\
\text { MEK inhibitors and other } \\
\text { investigational therapies }\end{array}$ \\
\hline
\end{tabular}

*Possible features. Refer to text/specific tables for criteria. PHGG : pediatric high grade glioma, LFS : Li Fraumeni syndrome, MB ${ }_{\text {SHH }}:$ Sonic Hedgehog medulloblastoma, CMMRD : constitutional mismatch repair deficiency, NF-1 : neurofibromatosis type 1, MPNST : malignant peripheral nerve sheath tumor, JMML : juvenile myelomonocytic leukemia, LGG : low grade glioma, A/E : adverse effects, MEK: MAPK/ERK kinase 
Table 2. Diagnostic clinical criteria of Li Fraumeni syndrome (LFS)

Classical Li Fraumeni Criteria ${ }^{46)}$ (all obligatory):
1. Proband diagnosed with sarcoma before 45 years of age, and
2. A first-degree relative with cancer before 45 years of age, and
3. Another first- or second-degree relative with any cancer diagnosed under 45 years of age or with sarcoma at any age
2015 version of Chompert Criteria ${ }^{14)}$ (only one obligatory):
1. Familial presentation : proband with tumor belonging to LFS tumor spectrum (e.g., premenopausal breast cancer, soft tissue sarcoma, osteosarcoma,
CNS tumor, adrenocortical carcinoma) before age 46 years, AND at least one first or second-degree relative with LFS tumor (except breast cancer if
proband has breast cancer) before age 56 years or with multiple tumors
2. Multiple primitive tumors : proband with multiple tumors (except multiple breast tumors), two of which belong to LFS tumor spectrum and first of
which occurred before age 46 years
3. Rare tumors: patient with adrenocortical carcinoma, choroid plexus tumor, or rhabdomyosarcoma of embryonal anaplastic subtype, irrespective of
family history
4. Early-onset breast cancer : breast cancer before age 31 years

CNS : central nervous system

While malignant gliomas are the most common brain tumor in LFS, they tend to occur during late childhood and adulthood. In the younger age group, choroid plexus carcinomas $(\mathrm{CPC})$ and Sonic $\mathrm{MB}_{\mathrm{SHH}}$ are more prominent ${ }^{68)}$. The prevalence of LFS among patients with CPC is extremely high : $36-50 \%$ of patients with this tumor harbor TP53 germline mutation $^{36}$. CPC is considered an LFS-defining tumor which obligates genetic testing to every patient with the tumor, regardless of family history ${ }^{103)}$. Similarly, half of children with SHH/TP53-mutated medulloblastomas harbor germline mutations in TP53 ${ }^{116)}$, and should be referred to genetic counselling as well. Tumors of astrocytic origin in the context of LFS include mostly high grade gliomas but lower grade gliomas have been observed ${ }^{10,16}$.

\section{Biological considerations}

TP53 is a tumor suppressor gene. The protein it encodes (p53) upregulates the transcription of target genes involved in cell cycle arrest, DNA repair, apoptosis and senescence, in response to DNA damage ${ }^{41)}$. The TP53 gene is located on chromosome $17 \mathrm{p} 13$ and more than 250 different germline alterations of it have been reported. While the genotypic : phenotypic correlations are not fully understood, most mutations in brain tumors reside within the DNA binding domain ${ }^{78}$. Brain tumors seem to cluster in certain families with LFS, possibly due to additional modifying genes ${ }^{55}$. Somatic inactivation of TP53 remains one of the most frequent genetic change identified in human cancer ${ }^{6,50)}$ including childhood glioblastoma ${ }^{799}$.

The biology of the glioma itself in individuals with LFS may differ. Watanabe et al. ${ }^{111}$ reported a rare type of IDH1 (R132C) in
LFS gliomas. Since IDH1 mutations are common in secondary glioblastomas of young adults which progress from lower-grade tumors $^{21,82)}$, these observations may be important for the management of these patients.

\section{Clinical implications}

\section{Diagnosis}

Histologically, CNS tumors associated with TP53 mutations are identical to their sporadic counterparts. Since TP53 mutations exist in up to $50 \%$ of PHGG, positive tumoral immunostain or even somatic mutation in TP53 does not correlate with germline mutations. Since LFS is a highly penetrant syndrome, clinical-familial diagnostic criteria are the main indication to search for the presence of TP53 germline mutation, which is sufficient for diagnosis ${ }^{34,94,104)}$.

\section{Management}

TP53 mutations were proven to be a negative prognostic factor in several tumor types, including $\mathrm{CPC}^{103)}, \mathrm{MB}^{100,116)}$, and $\mathrm{PHGG}^{27,83)}$. Therefore, with current treatment approaches, late detection of LFS gliomas when these are already PHGG may not be sufficient for curative intent. Since transformation of lower grade gliomas to PHGG have been reported ${ }^{13,102)}$ (Fig. 1), early detection and resection of a low grade lesion may offer improved survival for LFS individuals.

Villani et al. ${ }^{109)}$ demonstrated a survival advantage in patients with LFS undergoing intense tumor surveillance. Forty tumors were detected in 19 of 59 patients on surveillance, including 

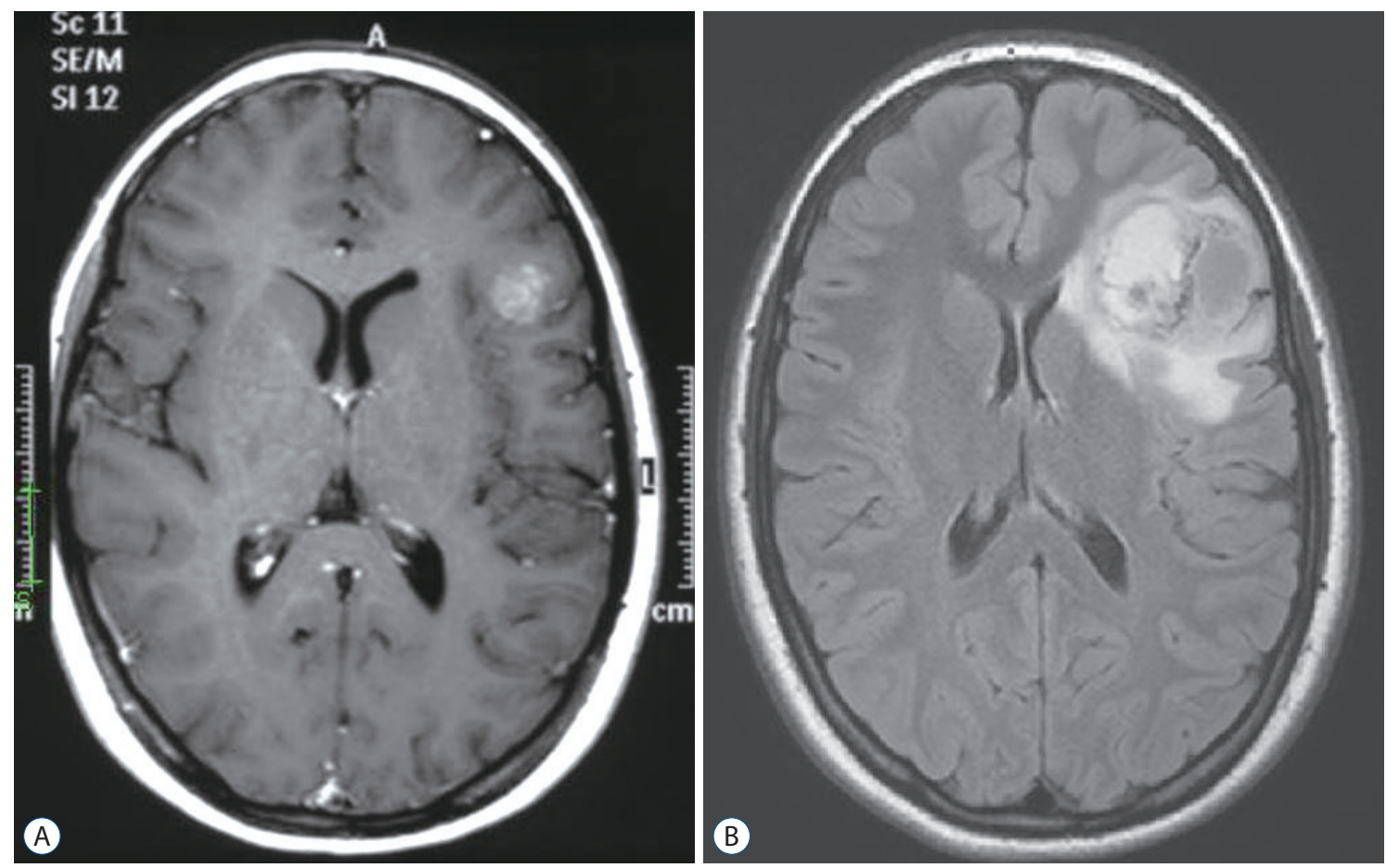

Fig. 1. Transformation of a low grade to high grade glioma in a patient with Li Fraumeni. A low grade glioma was diagnosed in a known LFS patient (A). Three years following the initial diagnosis, a sudden dramatic growth was observed (B). Biopsy confirmed the diagnosis of anaplastic astrocytoma (WHO grade III). LFS: Li Fraumeni syndrome, WHO: World Health Organization.

gliomas that were detected with brain magnetic resonance imaging (MRI). Furthermore, 25 of 40 tumors found on the surveillance protocol were low grade or premalignant at the time of detection, suggesting that early detection through surveillance may identify lesions before malignant transformation. Five-year overall survival was $88.8 \%$ versus $59.6 \%$ in individuals not undergoing surveillance. Other studies have recently confirmed improved clinical outcomes for TP53 mutation carriers with intensive screening ${ }^{10,14,92)}$. Complete resection of lower grade gliomas from LFS patients (Fig. 2) may improve survival by prevention of the transformation to PHGG.

Table 3 summarizes consensus recommendations made by an international expert group concerning surveillance of $\mathrm{LFS}^{57}$. The lifelong brain tumor risk justifies dedicated annual brain MRI. Annual whole body MRI that is recommended for solid tumor surveillance, cannot replace dedicated CNS imaging, as was proven by a recent meta-analysis ${ }^{10)}$, and ideally should alternate with the brain MRI every 6 months.

\section{Treatment}

Currently, there are no TP53 specific therapies and the prognosis for LFS-associated HGG remains poor ${ }^{102)}$. Since $\mathrm{p} 53$ plays a key role in response to DNA damage, the risk of secondary malignancies including PHGG post genotoxic damage from chemoradiation is high. Increased risk of therapy associated secondary malignancies in the radiation field was reported in number of cohorts and case reports ${ }^{16,42,44,63,65,96)}$. However, currently, taken the challenges of treating PHGG, there are no successful alternative treatment strategies for cancer in the context of LFS.

\section{CONSTITUTIONAL MISMATCH REPAIR DEFI- CIENCY (CMMRD)}

CMMRD is a childhood cancer syndrome caused by biallelic mutations in the mismatch repair pathway ${ }^{113)}$. Monoallelic mutations in MMR genes results in a CPS termed Lynch syndrome. This autosomal dominant syndrome presents with primarily gastrointestinal and genitourinary malignancies in mid to late adulthood. In contrast, biallelic mutations in the MMR genes causes complete loss of MMR ability in all cells resulting in CMMRD, an autosomal recessive syndrome with vast spectrum of malignancies and grave prognosis during childhood.

Previously, CMMRD was also termed as brain tumor-polyp- 
osis syndrome-1, biallelic MMRD (BMMRD), or Turcot syndrome type 1 . It is important to differentiate CMMRD from
Turcot type 2 (familial adenomatosis polyposis, FAP) which is an autosomal dominant syndrome caused by germline muta-
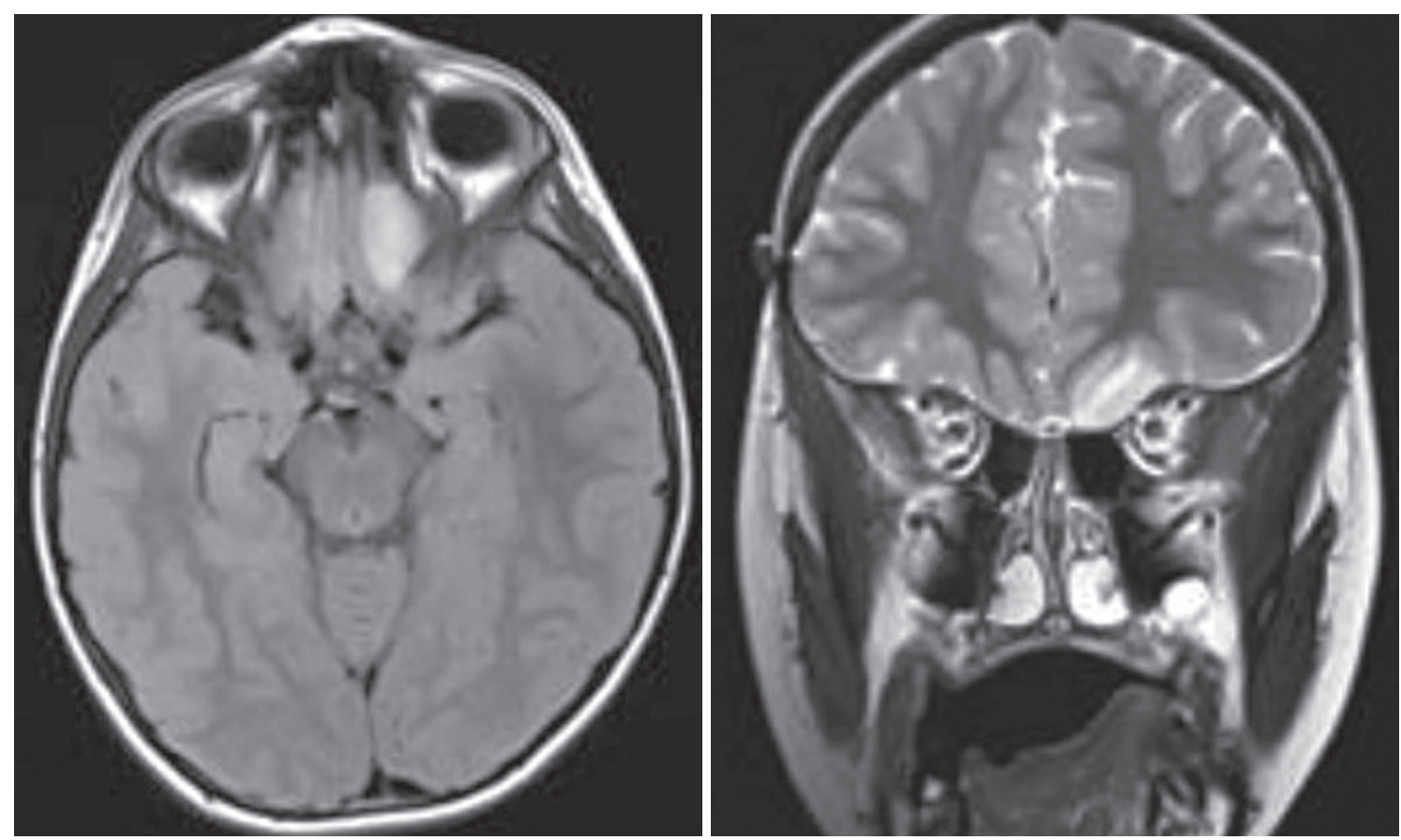

Fig. 2. Surveillance imaging reveals asymptomatic glioma in a Li Fraumeni patient. A routine surveillance imaging in an LFS patient reveals an intra-axial lesion within the inferior left frontal lobe. The lesion was fully resected, and the pathology revealed diffuse astrocytoma, WHO stage II. LFS : Li Fraumeni syndrome, WHO : World Health Organization.

Table 3. Recommended surveillance for brain tumors in selected CPS in the pediatric population $(<18$ years)*

\begin{tabular}{|c|c|c|c|c|c|}
\hline & Brain MRI frequency & Age for imaging & $\begin{array}{l}\text { Other tests for } \\
\text { brain lesions }\end{array}$ & $\begin{array}{l}\text { Surveillance for other } \\
\text { tumors } \\
\text { (age to start in years) }\end{array}$ & Comments \\
\hline LFS & Annually & $\begin{array}{l}\text { Start at diagnosis : Baseline } \\
\text { with GBCA, follow up } \\
\text { without GBCA unless } \\
\text { abnormality is seen }\end{array}$ & $\begin{array}{l}\text { Physical neurological } \\
\text { examination q3-4 } \\
\text { months }\end{array}$ & $\begin{array}{l}\text { Annual WBMRI } \\
\text { US (abdomen - pelvis) } \\
\text { q3-4 months } \\
\text { Endocrine function } \\
\text { q3-4 months } \\
\text { (all start from diagnosis) }\end{array}$ & $\begin{array}{l}\text { Annual WBMRI may } \\
\text { alternate with } \\
\text { annual brain MRI } \\
\text { (q6 months) in } \\
\text { non-anesthetised } \\
\text { children }\end{array}$ \\
\hline CMMRD & q6 months & $\begin{array}{l}\text { Start at diagnosis, } \\
\text { including infants }\end{array}$ & $\begin{array}{l}\text { Repeated neurological } \\
\text { examination }\end{array}$ & $\begin{array}{l}\text { WBMRI annually ( } 6 \text { years) } \\
\text { CBC } q 6 \text { months ( } 1 \text { year) } \\
\text { Abdominal US q6 months } \\
\text { ( } 1 \text { year) } \\
\text { Annual endoscopy } \\
\text { (6 years) }\end{array}$ & $\begin{array}{l}\text { Brain US and WBMRI - less } \\
\text { sensitive for brain lesions }\end{array}$ \\
\hline NF1 & $\begin{array}{l}\text { LGG- only if symptomatic } \\
\text { No imaging surveillance } \\
\text { for } \mathrm{HGG}\end{array}$ & NA & $\begin{array}{l}\text { Ophthalmology q6-12 } \\
\text { months (birth to } 8 \text { years) } \\
\text { Annual history and } \\
\text { physical exam including } \\
\text { pubertal development }\end{array}$ & $\begin{array}{l}\text { Dedicated physical } \\
\text { examination }\end{array}$ & \\
\hline
\end{tabular}

*For full surveillance guideline of these syndromes and others, please visit the site (http://clincancerres.aacrjournals.org/content/23/11), in case of positive findings continue as appropriate. CPS : cancer predisposition syndromes, MRI : magnetic resonance imaging, LFS : Li Fraumeni syndrome, GBCA : gadolinium based contrast agent, WBMRI : whole body MRI, US : ultrasound, CMMRD : constitutional mismatch repair deficiency, CBC : complete blood count, NF1 : neurofibromatosis type 1, LGG : low grade gliomas, HGG : high grade gliomas, NA : not applicable 
tions in the adenomatous polyposis coli (APC) gene. FAP has similar characteristics of numerous colonic adenomas and progression to colorectal carcinoma. However, brain tumors are rare and are almost exclusively related to medulloblastoma during childhood and rarely astrocytoma, ependymoma, and pinealoblastoma $^{108)}$.

\section{Biological considerations}

The mismatch repair system is one of the major DNA repair pathways in humans and is composed of several genes including MSH2, MSH6, MLH1, and PMS2 ${ }^{112)}$. Its primary function is to correct errors that arise during DNA replication. Hence, mutations in MMR genes lead to accumulation of somatic mutations in each cell division and can lead to hypermutant cancer. The two major types of mutations resulting from lack of MMR are point mutations (single nucleotide variations) and microsatellite instability (MSI) in which mutations repetitive sequences (microsatellites) are not adequately repaired.

Recently, other components of the replication repair machinery have been reported to be associate with similar clinical and biological presentation and cancer hypermutations. These included mutations in $\mathrm{MSH} 3^{1}$, deletions of the EPCAM gene, located just upstream of $\mathrm{MSH} 2^{64)}$ and mutations in DNA polymerases epsilon and delta 1 (POLE, POLD1) $)^{29,77)}$.

Since most mutations in the MMR genes result in lack of protein expression, there is no clear genotype phenotype correla- tion. However, in contrast to Lynch syndrome where MSH2 and MLH1 are the most common genes affected, PMS2 mutations are most frequent in CMMRD, followed by $\mathrm{MSH}^{113)}$.

\section{Clinical implications}

CMMRD patients frequently present with physical features, the most common being café au lait spots or other hyper- and hypopigmented skin alterations. Not infrequently they are misdiagnosed as NF1. Other features diagnostic for NF1 may be apparent as well but are far less frequent, including neurofibromas, freckling, Lisch nodules and others ${ }^{113,114)}$. Other physical finding that can sometime be found in CMMRD are venous anomalies, pilomatricomas (benign skin lesions), agenesis of the corpus callosum ${ }^{7}$, and decreased levels of immunoglobulins $\operatorname{IgG} 2 / 4$ and $\operatorname{Ig} \mathrm{A}^{113)}$. As it is an autosomal recessive syndrome, consanguinity is a common feature, however none of these clinical and familial features is obligatory ${ }^{60,113)}$.

Penetrance is extremely high reaching more than $90 \%$ at age 20 , hence almost all patients will have cancer as children. In fact, since mutations are so abundant in the setting of deficient corrective mechanisms, most individuals will have more than one tumor, which can occur metachronously or synchronously (Fig. 3).

PHGG constitute the most prevalent brain tumors in patients with MMR mutations, although medulloblastoma, supratentorial primitive neuroectodermal tumors and low grade glio-
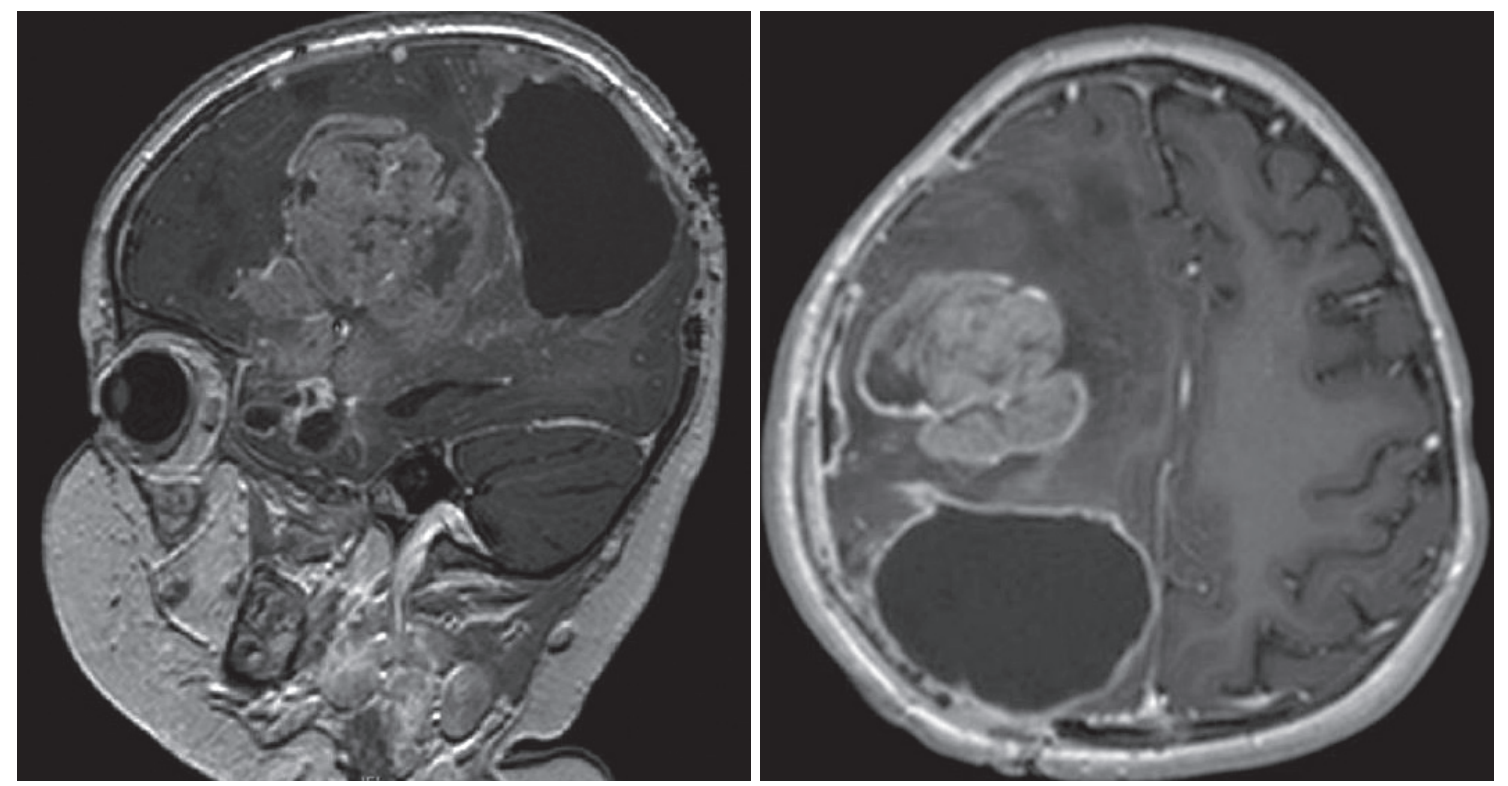

Fig. 3. Bifocal glioblastoma in a CMMRD patient. Two separate lesions uncovered in an infant with CMMRD. Molecular and genetic analysis confirmed two different glioblastomas and not metastatic disease. CMMRD : constitutional mismatch repair deficiency. 
mas have also been reported. Median age at diagnosis of brain is 9-10.3 years, nevertheless they were observed since infan$\mathrm{cy}^{9,60,113)}$. Other malignancies include hematological malignancies (mainly T-lymphoblastic lymphoma), early onset of colorectal cancers and virtually every organ can be affected.

\section{Diagnosis}

CMMRD should be suspected in children and adolescents with PHGG (or other malignancy) that have café au-lait macules, a history of Lynch syndrome in the family, or a sibling with childhood cancer. However, other features can occur as mentioned and thus high index of suspicion is required ${ }^{3,60,1011}$. Since PHGG are uncommon in neurofibromatosis-1 (NF-1), every child with "known" NF1 and a malignant tumor including PHGG during childhood should be investigated for CMMRD. Immunohistochemistry showing loss of one of the MMR proteins in both malignant and normal cells in the biopsy specimen is both sensitive and specific method for detection of CMMRD. This assay is available in most pathology laboratories as part of the routine workup of colon cancers in adults ${ }^{9}$. It will also guide target-gene mutation analysis for the corresponding mutated gene. However, some missense mutations will result in retained staining of the protein, hence a positive stain does not preclude a diagnosis of $\mathrm{CMMRD}^{60)}$. In contrast, MSI which is extremely useful tool in Lynch syndrome cancers, is not high in CMMRD cancers and especially in PHGG. This tool therefore, should not be used as it can cause false negative testing and mismanagement of patients and tumors.

High tumor mutational burden, which is rare in childhood cancers, has been described to be extremely specific to $\mathrm{CMMRD}^{5,45,99)}$. This vast numbers of mutations form a "signature" that is deeply engraved on the genome. In a recent study, this characteristic has been validated, as hypermutant childhood cancers were almost invariantly caused by replication repair deficiency and mutational burden and their signatures could be traced to the germline ${ }^{19)}$. Finding of such hyper mutant primary tumor should therefore be followed by testing for CMMRD.

The final confirmation of the diagnosis of CMMRD should come from the determination of the causative biallelic mutations of the patient. However, mutation analysis is frequently difficult in case of PMS2 due to pseudogenes and variance of unknown significance in others. Therefore, a combination of

Table 4. Diagnostic criteria that should raise the suspicion of CMMRD syndrome in a cancer patient* ( $\geq 3$ points needed)

\begin{tabular}{|c|c|}
\hline \multicolumn{2}{|l|}{ Malignancies/premalignancies : one is mandatory; if more than one is present in the patient, add the points } \\
\hline Carcinoma from the Lynch syndrome spectrum ${ }^{\dagger}$ at age $<25$ years & 3 points \\
\hline $\begin{array}{l}\text { Multiple bowel adenomas at age }<25 \text { years and absence of APC/MUTYH mutation (s) or a single high-grade dysplasia adenoma at age } \\
<25 \text { years }\end{array}$ & 3 points \\
\hline WHO grade III or IV glioma at age $<25$ years & 2 points \\
\hline NHL of T-cell lineage or sPNET at age $<18$ years & 2 points \\
\hline Any malignancy at age $<18$ years & 1 point \\
\hline \multicolumn{2}{|l|}{ Additional features : optional; if more than one of the following is present, add the points } \\
\hline Clinical sign of NF1 and/or $\geq 2$ hyperpigmented and/or hypopigmented skin alterations $\varnothing>1 \mathrm{~cm}$ in the patient & 2 points \\
\hline Diagnosis of LS in a first-degree or second-degree relative & 2 points \\
\hline Carcinoma from LS spectrum ${ }^{\dagger}$ before the age of 60 in first-degree, second-degree, and third-degree relative & 1 point \\
\hline A sibling with carcinoma from the LS spectrum ${ }^{\dagger}$, high-grade glioma, sPNET or NHL & 2 points \\
\hline A sibling with any type of childhood malignancy & 1 point \\
\hline Multiple pilomatricomas in the patient & 2 points \\
\hline One pilomatricoma in the patient & 1 point \\
\hline Agenesis of the corpus callosum or non-therapy-induced cavernoma in the patient & 1 point \\
\hline Consanguineous parents & 1 point \\
\hline Deficiency/reduced levels of $\lg G 2 / 4$ and/or $\lg A$ & 1 point \\
\hline
\end{tabular}

*Adapted from the recommendations of the European consortium 'Care for $\mathrm{CMMRD}^{47)}$. ${ }^{\dagger}$ Colorectal, endometrial, small bowel, ureter, renal pelvis, biliary tract, stomach, bladder carcinoma. CMMRD : constitutional mismatch repair deficiency, WHO : World Health Organization, NHL : non-Hodgkin's lymphomas, sPNET : supratentorial primitive neuroectodermal tumours, NF1 : neurofibromatosis type 1, LS : Lynch syndrome 
clinical parameters (Table 4) and the above functional assays may be required.

\section{Management}

Once diagnosed, surveillance is crucial, as most children with CMMRD will be affected with cancer. A consensus surveillance protocol was established and published by the American Academy of Cancer Research ${ }^{101)}$ and other groups ${ }^{25)}$, and it's summery is depicted in Table 3. Since CNS tumors are observed from infancy, imaging is recommended as soon as the diagnosis is done, and should be done every 6 months. MRI is the gold standard and ultrasonographic assessment cannot replace it, even in the setting of open fontanelle.

\section{Treatment}

There is currently no evidence of extensive toxicity of chemoradiation in CMMRD patients ${ }^{60)}$. In contrast to other DNA damage repair deficiencies, repair of external insults is maintained as MMR is responsible for mistakes which occur during replication only. However, there is known tumor resistance to several common chemotherapeutic agents which require adequate mismatch repair to exert their tumor damage. These include Temozolomide, which is vastly used for PHGG treatment ${ }^{54)}$.

Tumors with high mutational load have increased formation of neo-antigen, which may serve as targets for the immune system $^{24,61,88)}$. This observation proved to be clinically significant in CMMRD PHGG as immune checkpoint inhibition was shown to have significant effect in prolonging survival for two patients with CMMRD recurrent glioblastoma ${ }^{15)}$. It also held true in a patient with hypermutant glioblastoma multiforme (GBM) and POLE germline ${ }^{49)}$, and in non-CNS cancers ${ }^{61,88,91)}$. Recently the Food and Drug Administration (FDA) approved the PD-1 inhibitor pembrolizumab for the treatment of mismatch-repairdeficient cancers ${ }^{62)}$. These approaches and in combinations with others offer hope for patients with CMMRD PHGG and active pursue of international clinical trial is recommended.

\section{NEUROFIBROMATOSIS TYPE 1 (NF1)}

NF1 (von Recklinghausen disease) is the most common CPS, with an incidence of $1: 2000-1: 5000$. As most CPS it is autosomal dominant, however the occurrence of cancers is only a part of this clinical syndrome. Approximately half of the cases occur de novo with no familial history ${ }^{31)}$. The clinical diagnosis requires the fulfilment of at least two of the criteria (Table 5), however there are other possible manifestations, including macrocephaly, learning disabilities, vasculopathies, scoliosis among others. Penetrance is complete with some degree of clinical manifestations in every individual harboring a mutation ${ }^{48)}$.

\section{Biological considerations}

NF1 gene is a tumor suppressor gene located on chromosome 17q11.2. It encodes the protein Neurofibromin, a GTPaseactivating protein (GAPs) that inhibits the RAS oncogene by transforming GTP-RAS to GDP-RAS. RAS is an important activator of various signaling pathways, including the MAPK (RAF-MEK-ERK) and the PI3K/AKT/mTOR pathways ${ }^{93)}$. As a consequence, a malfunction of its inhibitor results in increased proliferation and tumorigenesis. Importantly, since inhibitors exist for both pathways, NF1 mutations may be targetable for therapy.

\section{Clinical implications}

Most NF1 tumors are of benign nature. However, NF1 patients are at risk for malignant tumors including peripheral nerve sheath tumors (MPNST), PHGG and juvenile myelomonocytic leukemia (JMML) among others ${ }^{48)}$. As for NF1 gliomas, these should be differentiated from foci of abnormal signal intensity (FASI), also termed UBOs (unidentified bright objects). These multiple, non-enhancing, small areas without mass effect or edema are benign, and are found in 70\% of NF1 pediatric cases ${ }^{52}$.

The most common CNS neoplasia in NF1 is optic pathway glioma (OPG), that tend to arise in infancy and affect approximately $15-20 \%$ of individuals with $\mathrm{NF}^{2}{ }^{2}$. These OPGs are usually pilocytic or pilomyxoid astrocytomas. They can involve all

Table 5. NF1 clinical criteria

Six or more café-au-lait macules $>5 \mathrm{~mm}$ in diameter in prepubertal and $>15 \mathrm{~mm}$ in diameter in postpubertal individuals

Two or more neurofibromas of any type or one plexiform neurofibroma Freckling in the axillary or inguinal regions

Optic glioma

Two or more Lisch nodules (iris hamartomas)

A distinctive bony lesion, such as sphenoid dysplasia or thickening of

the long bone cortex with or without pseudoarthrosis

A first-degree relative with NF1 based upon the above criteria

NF1 : neurofibromatosis type 1 
parts of the optic tract; however, bilateral involvement of the optic nerves is highly suggestive of $\mathrm{NF}^{90)}$.

The rate of higher grade brain malignancies in NF1 is much lower. However, as shown in Fig. 4, this entity should not be underestimated $^{38,73,89,107)}$. Molecularly, NF1-PHGG share the same molecular abnormalities as non-syndromic patients, including secondary TP53 mutations and CDKN2A/p16 deletions ${ }^{39)}$. Similarly, NF1 is one of the most frequently mutated somatic genes in sporadic glioblastoma ${ }^{20,58,102)}$. It is still unclear whether NF1PHGG are secondary gliomas arising from low grade lesions or can be primary PHGG $^{46,102)}$.

\section{Diagnosis}

Although NF1 is traditionally diagnosed clinically, most of the features develop gradually and do not necessarily appear in the first months of life. Furthermore, other conditions with NF1 stigmata are known and include Legius syndrome and other RASopathies. Importantly, CMMRD (see above) can mimic NF-1 and the current expert consensus state that in the case of high-grade tumors including PHGG in a child with NF1, a genetic testing should be performed ${ }^{30)}$. Genetic testing is thereby currently the standard of care. It is indicated for familial rea- sons, as well as for insuring correct NF1 diagnosis.

\section{Management}

Although the rate of optic gliomas is high, the role of surveillance neuroimaging in asymptomatic children with NF1 is still controversial $^{32,37,53,66,74)}$. Furthermore, since PHGG is uncommon in NF1, surveillance by imaging cannot be recommend$\mathrm{ed}^{30,43)}$. Close monitoring with repeated ophthalmologic examinations and physical examination is the standard of care, and should include neurological examination and signs of endocrine malfunction ${ }^{30,37,43,66,81)}$ (Table 3). Families should be informed about the clinical warning signs of brain tumors and any evolving signs or symptoms should prompt investigations.

\section{Treatment}

In the case of imaging progression in conjunction with symptoms, medical therapy is often the modality of choice for low grade gliomas. Radiotherapy is not recommended due to numerous reports of complications specifically in the NF1 population. These sequela includes secondary malignancies and vascular complications, namely stroke ${ }^{37,75,89)}$. Radiation as the cause of malignant transformation was emphasised in a study by
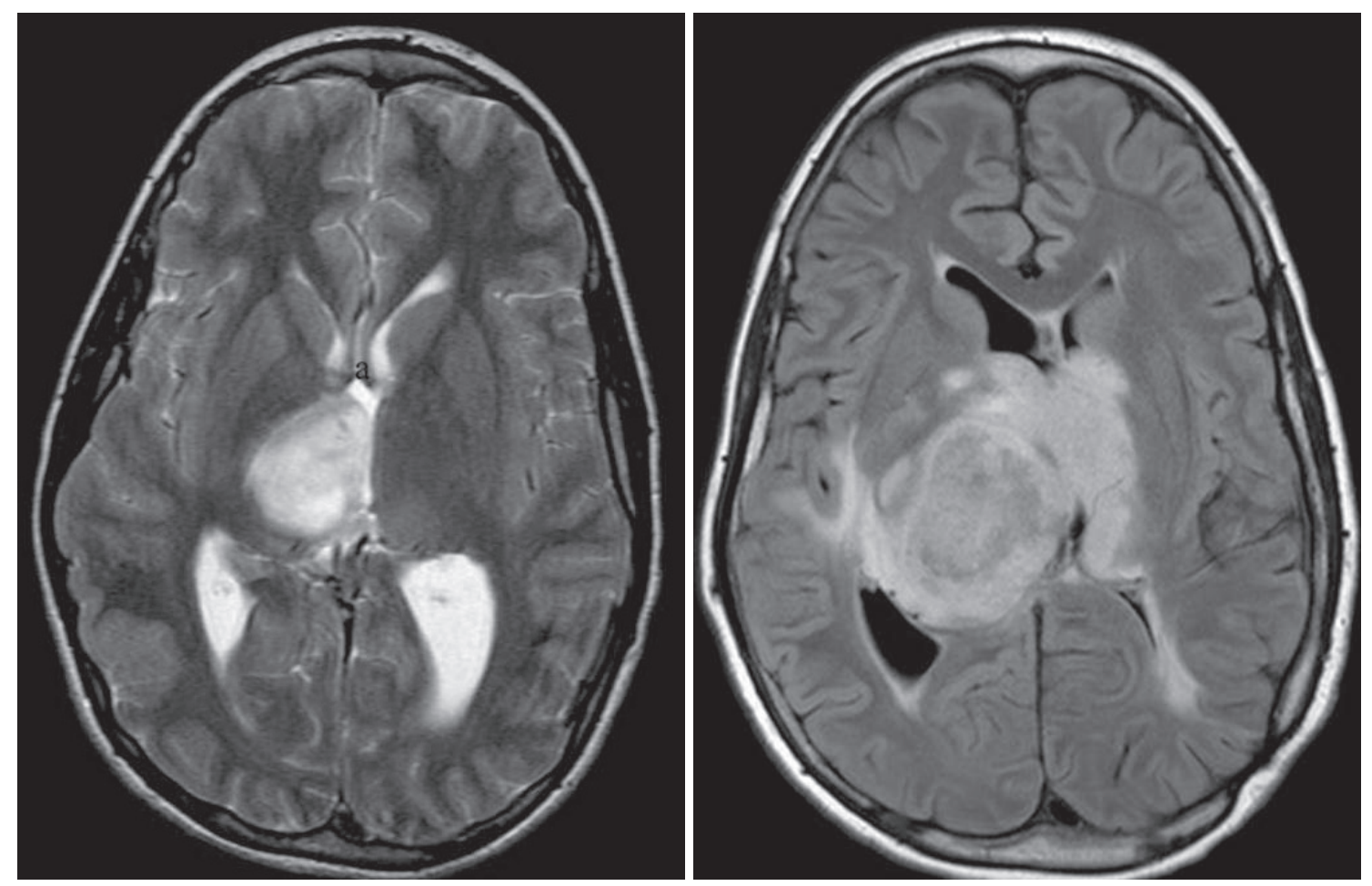

Fig. 4. Malignant glioma in a NF-1 patient. Rapidly growing thalamic lesion in a patient with NF-1 exhibiting significant mass effect and edema. Pathology confirmed PHGG. NF-1 : neurofibromatosis-1, PHGG : pediatric high grade gliomas. 
Sharif et al. ${ }^{95)}$, where the relative risk for developing a secondary malignancy was 3.04 in NF1 patients treated by radiotherapy, compared with NF1 patients who did not receive radiation.

The treatment of NF1 PHGG is similar to sporadic cases. Although some indications exist that prognosis may be better than sporadic PHGG and prolonged disease is commonly reported, cure is not common ${ }^{18,22,40,46,98,105,106)}$.

MEK inhibitors, which have shown success in NF1 patients with low grade glioma ${ }^{11)}$, may offer improved outcome either alone or in combination with other therapies for NF1-PHGG.

\section{OTHER CANCER PREDISPOSITION SYNDROMES}

Other syndromes have been also associated less commonly with malignant gliomas. It is important to distinguish case reports from real increased risk for PHGG. Such CPS where there is no current data of increased risk include $\mathrm{BRCA}^{28,33)}$, tuberous sclerosis $^{87)}$, multiple enchondromatosis ${ }^{85)}$, Fanconi anemia ${ }^{23)}$, Beckwith Widemann syndrome and more ${ }^{12}$. Adult syndromes can cause HGG but are rare in childhood. Familial melanoma astrocytoma is a CPS caused by inactivating germline alteration of the CDKN2A tumor suppressor gene. Individuals can develop both melanomas and astrocytomas (predominantly GBM), and occasionally other nervous-system neoplasms including peripheral nerve sheath tumors and meningiomas ${ }^{51,84)}$.

All of the aforementioned are cancer predisposition syndromes with a known single locus etiology. However, there are numerous cases in which we encounter a patient with a rich familial history, but none of the known germline mutations are found. Moreover, studies have shown families with an aggregation of gliomas, with up to a three-fold increased risk of glioma among close relatives ${ }^{72)}$. A large study that included 5088 relatives of 639 probands diagnosed with a glioma under age 65 years, showed that such "familial glioma" are probably a result of multigenic action, and may involve unknown environmental exposures ${ }^{4}$. GLIOGENE is an international consortium which was formed in order to collect such non-syndromic glioma families, and identify new important genomic loci. Linkage studies have suggested linkage on chromosome $17 \mathrm{q}^{47,97)}$ but it is yet to be determined whether there is a clear disease causing mechanism. Exome sequencing of families in this consortium identified protection of telomerase protein 1 (POT1), which has also been implicated in melanomas, as potential glioma causing gene $^{8)}$. All of these may not cause or be associated with increased risk of PHGG and be more relevant to adults.

\section{SUMMARY AND RECOMMENDATIONS}

This review outlined the important role of several CPS in PHGG. Knowledge of specific CPS may alter the management of the cancer, avoid unnecessary treatment and offer novel targeted therapies which may improve survival for these patients. Furthermore, recognition of CPS may affect survival for other family members of children affected by PHGG.

As a result, when encountered with a PHGG, the physician should consider the possibility of CPS. Features of LFS, CMMRD and NF1 as mentioned above should raise a suspicion. However, even if their absence, other "universal criteria" are suggestive of a $\mathrm{CPS}^{35}$. These include any child with more than one primary tumor, a known CPS, or cancers in young family members, and should prompt referral to genetic testing.

If any of the above indications exist for suspecting a CPS, genetic counselling must be offered to the patient and their parents prior to performing mutation analysis. Psychological support should be offered, as identifying CPS has important implications not only to the proband but to his whole family, which needs to be genetically consulted as well.

Finally, consulting experts in the field of CPS can improve the management of the patient with CPS related PHGG and guide implementation of surveillance, preventive and potential therapies for other family members. In an era of precision medicine, molecular based therapies must be conjoined with thorough understanding of genetic causes of cancers, especially in children affected by PHGG.

\section{CONFLICTS OF INTEREST}

No potential conflict of interest relevant to this article was reported.

\section{INFORMED CONSENT}

This type of article does not require informed consent. 


\section{References}

1. Adam R, Spier I, Zhao B, Kloth M, Marquez J, Hinrichsen I, et al. : Exome sequencing identifies biallelic MSH3 germline mutations as a recessive subtype of colorectal adenomatous polyposis. Am J Hum Genet 99 : 337-351, 2016

2. Albers $A C$, Gutmann $D H$ : Gliomas in patients with neurofibromatosis type 1. Expert Rev Neurother $9:$ 535-539, 2009

3. Amayiri N, Tabori U, Campbell B, Bakry D, Aronson M, Durno C, et al. : High frequency of mismatch repair deficiency among pediatric high grade gliomas in Jordan. Int J Cancer 138 : 380-385, 2016

4. de Andrade KC, Mirabello L, Stewart DR, Karlins E, Koster R, Wang M, et al. : Higher-than-expected population prevalence of potentially pathogenic germline TP53 variants in individuals unselected for cancer history. Hum Mutat 38 : 1723-1730, 2017

5. Andrianova MA, Chetan GK, Sibin MK, Mckee T, Merkler D, Narasinga RK, et al. : Germline PMS2 and somatic POLE exonuclease mutations cause hypermutability of the leading DNA strand in biallelic mismatch repair deficiency syndrome brain tumours. J Pathol 243 : 331-341, 2017

6. Aubrey BJ, Strasser A, Kelly GL : Tumor-suppressor functions of the TP53 pathway. Cold Spring Harb Perspect Med 6 : a026062, 2016

7. Baas AF, Gabbett M, Rimac M, Kansikas M, Raphael M, Nievelstein RAJ, et al. : Agenesis of the corpus callosum and gray matter heterotopia in three patients with constitutional mismatch repair deficiency syndrome. Eur J Hum Genet 21 : 55-61, 2013

8. Bainbridge MN, Armstrong GN, Gramatges MM, Bertuch AA, Jhangiani $\mathrm{SN}$, Doddapaneni $\mathrm{H}$, et al. : Germline mutations in shelterin complex genes are associated with familial glioma. J Natl Cancer Inst 107 : 384, 2015

9. Bakry D, Aronson M, Durno C, Rimawi H, Farah R, Alharbi QK, et al. : Genetic and clinical determinants of constitutional mismatch repair deficiency syndrome: report from the constitutional mismatch repair deficiency consortium. Eur J Cancer 50 : 987-996, 2014

10. Ballinger ML, Best A, Mai PL, Khincha PP, Loud JT, Peters JA, et al. : Baseline surveillance in Li-Fraumeni syndrome using whole-body magnetic resonance imaging. JAMA Oncol 3 : 1634-1639, 2017

11. Banerjee A, Jakacki RI, Onar-Thomas A, Wu S, Nicolaides T, Young Poussaint T, et al. : A phase I trial of the MEK inhibitor selumetinib (AZD6244) in pediatric patients with recurrent or refractory low-grade glioma: a Pediatric Brain Tumor Consortium (PBTC) study. Neuro Oncol 19 : 11351144, 2017

12. Bleeker FE, Hopman SMJ, Merks JHM, Aalfs CM, Hennekam RC : Brain tumors and syndromes in children. Neuropediatrics 45 : 137-161, 2014

13. Bögler $\mathrm{O}$, Su Huang HJ, Kleihues $P$, Cavenee WK : The p53 gene and its role in human brain tumors. Glia 15 : 308-327, 1995

14. Bojadzieva J, Amini B, Day SF, Jackson TL, Thomas PS, Willis BJ, et al. : Whole body magnetic resonance imaging (WB-MRI) and brain MRI baseline surveillance in TP53 germline mutation carriers: experience from the Li-Fraumeni Syndrome Education and Early Detection (LEAD) clinic. Fam Cancer, 2017 [Epub ahead of print]

15. Bouffet $E$, Larouche V, Campbell BB, Merico D, De Borja R, Aronson M, et al. : Immune checkpoint inhibition for hypermutant glioblastoma multiforme resulting from germline biallelic mismatch repair deficiency. J Clin Oncol 34 : 2206-2211, 2016

16. Bougeard G, Renaux-Petel M, Flaman JM, Charbonnier C, Fermey P, Belotti $M$, et al. : Revisiting Li-Fraumeni syndrome from TP53 mutation carriers. J Clin Oncol 33 : 2345-2352, 2015

17. Brodeur GM, Nichols KE, Plon SE, Schiffman JD, Malkin D : Pediatric cancer predisposition and surveillance: an overview, and a tribute to Alfred $\mathrm{G}$. Knudson Jr. Clin Cancer Res 23 : e1-e5, 2017

18. Broekman ML, Risselada R, Engelen-Lee J, Spliet WG, Verweij BH : Glioblastoma multiforme in the posterior cranial fossa in a patient with neurofibromatosis type I. Case Rep Med 2009 : 757898, 2009

19. Campbell BB, Light N, Fabrizio D, Zatzman M, Fuligni F, de Borja R, et al. : Comprehensive analysis of hypermutation in human cancer. Cell 171 : 1042-1056.e10, 2017

20. Cancer Genome Atlas Research Network : Comprehensive genomic characterization defines human glioblastoma genes and core pathways. Nature 455 : 1061-1068, 2008

21. Cruz GR, Dias Oliveira I, Moraes L, Del Giudice Paniago M, De Seixas Alves MT, Capellano AM, et al. : Analysis of KIAA1549-BRAF fusion gene expression and IDH1/IDH2 mutations in low grade pediatric astrocytomas. J Neurooncol 117 : 235-242, 2014

22. Distelmaier F, Fahsold R, Reifenberger $G$, Messing-Juenger $M$, Schaper J, Schneider DT, et al. : Fatal glioblastoma multiforme in a patient with neurofibromatosis type I: the dilemma of systematic medical follow-up. Child's Nerv Syst $23: 343-347,2007$

23. Dodgshun AJ, Sexton-Oates A, Saffery R, Sullivan MJ : Biallelic FANCD1/ BRCA2 mutations predisposing to glioblastoma multiforme with multiple oncogenic amplifications. Cancer Genet 209 : 53-56, 2016

24. Dudley JC, Lin MT, Le DT, Eshleman JR : Microsatellite instability as a biomarker for PD-1 blockade. Clin Cancer Res 22 : 813-820, 2016

25. Durno C, Boland CR, Cohen S, Dominitz JA, Giardiello FM, Johnson DA, et al. : Recommendations on surveillance and management of biallelic mismatch repair deficiency (BMMRD) syndrome: a consensus statement by the US multi-society task force on colorectal cancer. Gastroenterology 152 : 1605-1614, 2017

26. Eaton KW, Tooke LS, Wainwright LM, Judkins AR, Biegel JA : Spectrum of SMARCB1/INI1 mutations in familial and sporadic rhabdoid tumors. Pediatr Blood Cancer 56 : 7-15, 2011

27. Eisenstat DD, Pollack IF, Demers A, Sapp MV, Lambert P, Weisfeld-Adams $J D$, et al. : Impact of tumor location and pathological discordance on survival of children with midline high-grade gliomas treated on Children's Cancer Group high-grade glioma study CCG-945. J Neurooncol 121 : 573-581, 2015

28 Elmariah SB, Huse J, Mason B, Leroux P, Lustig RA : Multicentric glioblastoma multiforme in a patient with BRCA-1 invasive breast cancer. Breast J $12: 470-474,2006$

29. Esteban-Jurado C, Giménez-Zaragoza D, Muñoz J, Franch-Expósito $S$, Álvarez-Barona M, Ocaña T, et al. : POLE and POLD1 screening in 155 patients with multiple polyps and early-onset colorectal cancer. Oncotarget 8 : 26732-26743, 2017 
30. Evans DGR, Salvador H, Chang VY, Erez A, Voss SD, Schneider KW, et al. : Cancer and central nervous system tumor surveillance in pediatric neurofibromatosis 1. Clin Cancer Res 23 : e46-e53, 2017

31. Ferner RE, Huson SM, Thomas N, Moss C, Willshaw H, Evans DG, et al. : Guidelines for the diagnosis and management of individuals with neurofibromatosis 1. J Med Genet 44 : 81-88, 2006

32. Fisher MJ, Loguidice M, Gutmann DH, Listernick R, Ferner RE, Ullrich NJ, et al. : Visual outcomes in children with neurofibromatosis type 1-associated optic pathway glioma following chemotherapy: a multicenter retrospective analysis. Neuro Oncol 14 : 790-797, 2012

33. Girardstein-Boccara L, Mari V, Met-Domestici M, Burel-Vandenbos F, Berthet $\mathrm{P}$, Paquis $\mathrm{P}$, et al. : Gliomas and BRCA genes mutations: fortuitous association or imputability? Bull Cancer 101 : 795-802, 2014

34. Gonzalez KD, Noltner KA, Buzin CH, Gu D, Wen-Fong CY, Nguyen VQ, et al. : Beyond Li Fraumeni syndrome: clinical characteristics of families with p53 germline mutations. J Clin Oncol 27 : 1250-1256, 2009

35. Goudie C, Coltin H, Witkowski L, Mourad S, Malkin D, Foulkes WD : The McGill Interactive Pediatric OncoGenetic Guidelines: an approach to identifying pediatric oncology patients most likely to benefit from a genetic evaluation. Pediatr Blood Cancer 64 : e26441, 2017

36. Gozali AE, Britt B, Shane L, Gonzalez I, Gilles F, McComb JG, et al. : Choroid plexus tumors; management, outcome, and association with the LiFraumeni syndrome: the Children's Hospital Los Angeles (CHLA) experience, 1991-2010. Pediatr Blood Cancer 58 : 905-909, 2012

37. Grill J, Laithier V, Rodriguez D, Raquin MA, Pierre-Kahn A, Kalifa C : When do children with optic pathway tumours need treatment? An oncological perspective in 106 patients treated in a single centre. Eur J Pediatr 159 : 692-696, 2000

38. Guillamo JS, Créange A, Kalifa C, Grill J, Rodriguez D, Doz F, et al. : Prognostic factors of CNS tumours in Neurofibromatosis 1 (NF1): a retrospective study of 104 patients. Brain 126(Pt 1) : 152-160, 2003

39. Gutmann DH, James CD, Poyhonen $M$, Louis DN, Ferner $R$, Guha $A$, et al. : Molecular analysis of astrocytomas presenting after age 10 in individuals with NF1. Neurology 61 : 1397-1400, 2003

40. Hakan T, Aker FV : Case report on a patient with neurofibromatosis type 1 and a frontal cystic glioblastoma. Neurol Neurochir Pol 42 : 362-365, 2008

41. Hanahan D, Weinberg RA : Hallmarks of cancer: the next generation. Cell $144:$ 646-674, 2011

42. Henry E, Villalobos V, Million L, Jensen KC, West R, Ganjoo K, et al. : Chest wall leiomyosarcoma after breast-conservative therapy for early-stage breast cancer in a young woman with Li-Fraumeni syndrome. J Natl Compr Canc Netw 10 : 939-942, 2012

43. Hersh JH; American Academy of Pediatrics Committee on Genetics : Health supervision for children with neurofibromatosis. Pediatrics 121 : 633-642, 2008

44. Heymann S, Delaloge S, Rahal A, Caron O, Frebourg T, Barreau L, et al. : Radio-induced malignancies after breast cancer postoperative radiotherapy in patients with Li-Fraumeni syndrome. Radiat Oncol 5 : 104, 2010

45. Hodges TR, Ott M, Xiu J, Gatalica Z, Swensen J, Zhou S, et al. : Mutational burden, immune checkpoint expression, and mismatch repair in glioma: implications for immune checkpoint immunotherapy. Neuro Oncol 19 : 1047-1057, 2017

46. Huttner AJ, Kieran MW, Yao X, Cruz L, Ladner J, Quayle K, et al. : Clinicopathologic study of glioblastoma in children with neurofibromatosis type 1. Pediatr Blood Cancer 54 : 890-896, 2010

47. Jalali A, Amirian ES, Bainbridge MN, Armstrong GN, Liu Y, Tsavachidis S, et al. : Targeted sequencing in chromosome 17q linkage region identifies familial glioma candidates in the Gliogene consortium. Sci Rep 5 : 8278, 2015

48. Jett K, Friedman JM : Clinical and genetic aspects of neurofibromatosis 1. Genet Med 12 : 1-11, 2010

49. Johanns TM, Miller CA, Dorward IG, Tsien C, Chang E, Perry A, et al. : Immunogenomics of hypermutated glioblastoma: a patient with germline POLE deficiency treated with checkpoint blockade immunotherapy. Cancer Discov 6 : 1230-1236, 2016

50. Kandoth C, Mclellan MD, Vandin F, Ye K, Niu B, Lu C, et al. : Mutational landscape and significance across 12 major cancer types. Nature 502 : 333-339, 2013

51. Kaufman DK, Kimmel DW, Parisi JE, Michels VV : A familial syndrome with cutaneous malignant melanoma and cerebral astrocytoma. Neurology 43 : 1728-1731, 1993

52. Khatua S, Gutmann DH, Packer RJ : Neurofibromatosis type 1 and optic pathway glioma: molecular interplay and therapeutic insights. Pediatr Blood Cancer 65 : e26838, 2017

53. King A, Listernick R, Charrow J, Piersall L, Gutmann DH : Optic pathway gliomas in neurofibromatosis type 1: the effect of presenting symptoms on outcome. Am J Med Genet 122A : 95-99, 2003

54. Kinsella TJ : Coordination of DNA mismatch repair and base excision repair processing of chemotherapy and radiation damage for targeting resistant cancers. Clin Cancer Res 15 : 1853-1859, 2009

55. Kleihues $P$, Schäuble B, zur Hausen A, Estève J, Ohgaki H : Tumors associated with $p 53$ germline mutations: a synopsis of 91 families. Am J Pathol $150: 1-13,1997$

56. Knapke S, Nagarajan R, Correll J, Kent D, Burns K : Hereditary cancer risk assessment in a pediatric oncology follow-up clinic. Pediatr Blood Cancer $58:$ : 85-89, 2012

57. Kratz CP, Achatz Ml, Brugières L, Frebourg T, Garber JE, Greer MC, et al. : Cancer screening recommendations for individuals with Li-Fraumeni syndrome. Clin Cancer Res 23 : e38-e45, 2017

58. Kyritsis AP, Bondy ML, Rao JS, Sioka C : Inherited predisposition to glioma. Neuro Oncol 12 : 104-113, 2010

59. Lalloo F, Varley J, Ellis D, Moran A, O'Dair L, Pharoah P, et al. : Prediction of pathogenic mutations in patients with early-onset breast cancer by family history. Lancet 361 : 1101-1102, 2003

60. Lavoine N, Colas C, Muleris M, Bodo S, Duval A, Entz-Werle N, et al. : Constitutional mismatch repair deficiency syndrome: clinical description in a French cohort. J Med Genet $52:$ 770-778, 2015

61. Le DT, Uram JN, Wang H, Bartlett BR, Kemberling H, Eyring AD, et al. : PD-1 blockade in tumors with mismatch-repair deficiency. N Engl J Med 372 : 2509-2520, 2015

62. Lemery S, Keegan P, Pazdur R : First FDA approval agnostic of cancer site - 
when a biomarker defines the indication. N Engl J Med 377 : 1409-1412, 2017

63. Li FP, Fraumeni JF Jr, Mulvihill JJ, Blattner WA, Dreyfus MG, Tucker MA, et al. : A cancer family syndrome in twenty-four kindreds. Cancer Res 48 : 5358-5362, 1988

64. Ligtenberg MJL, Kuiper RP, Chan TL, Goossens M, Hebeda KM, Voorendt $M$, et al. : Heritable somatic methylation and inactivation of MSH2 in families with Lynch syndrome due to deletion of the 3 ' exons of TACSTD1.

Nat Genet 41 : 112-117, 2009

65. Limacher JM, Frebourg T, Natarajan-Ame S, Bergerat JP : Two metachronous tumors in the radiotherapy fields of a patient with Li-Fraumeni syndrome. Int J Cancer 96 : 238-242, 2001

66. Listernick R, Ferner RE, Liu GT, Gutmann DH : Optic pathway gliomas in neurofibromatosis-1: controversies and recommendations. Ann Neurol 61 : 189-198, 2007

67. Louis DN, Ohgaki H, Wiestler OD, Cavenee WK : WHO classification of tumours of the central nervous system, ed 4. Lyon : International Agency for Research on Cancer Publications, 2016

68. Louis DN, Perry A, Reifenberger G, von Deimling A, Figarella-Branger D, Cavenee WK, et al. : The 2016 World Health Organization Classification of tumors of the central nervous system: a summary. Acta Neuropathol $131: 803-820,2016$

69. Mai P, Malkin D, Garber JE, Schiffman JD Weitzel JN, Strong LC, et al. : LiFraumeni syndrome: report of a clinical research workshop and creation of a research consortium. Cancer Genet 205 : 479-487, 2012

70. Malkin D : Li-Fraumeni syndrome. Genes Cancer 2 : 475-484, 2011

71. Malkin D, Li FP, Strong LC, Fraumeni JF Jr, Nelson CE, Kim DH, et al. : Germ line p53 mutations in a familial syndrome of breast cancer, sarcomas, and other neoplasms. Science 250 : 1233-1238, 1990

72. Malmer B, Adatto P, Armstrong G, Barnholtz-Sloan J, Bernstein JL, Claus E, et al. : GLIOGENE an international consortium to understand familial glioma. Cancer Epidemiol Biomarkers Prev 16 : 1730-1734, 2007

73. McKeever K, Shepherd CW, Crawford H, Morrison PJ : An epidemiological, clinical and genetic survey of neurofibromatosis type 1 in children under sixteen years of age. Ulster Med J 77 : 160-163, 2008

74. Menor F, Martí-Bonmatí L, Mulas F, Cortina H, Olagüe R : Imaging considerations of central nervous system manifestations in pediatric patients with neurofibromatosis type 1. Pediatr Radiol 21 : 389-394, 1991

75. Miaux Y, Guermazi A, Cornu P, Mokhtari K, Singer B, Chiras J, et al. : Highintensity lesion on T1-weighted MR images in neurofibromatosis type 1 : a case of premalignant lesion. Acta Neurochir (Wien) 139 : 10851087, 1997

76. Mody RJ, Wu YM, Lonigro RJ, Cao X, Roychowdhury S, Vats P, et al. : Integrative clinical sequencing in the management of refractory or relapsed cancer in youth. JAMA $314:$ 913-925, 2015

77. Nebot-Bral L, Brandao D, Verlingue L, Rouleau E, Caron O, Despras E, et al. : Hypermutated tumours in the era of immunotherapy: the paradigm of personalised medicine. Eur J Cancer 84 : 290-303, 2017

78. Olivier M, Goldgar DE, Sodha N, Ohgaki H, Kleihues P, Hainaut $P$, et al. : Li-Fraumeni and related syndromes: correlation between tumor type, family structure, and TP53 genotype. Cancer Res 63 : 6643-6650, 2003
79. Parsons DW, Jones S, Zhang X, Lin JC, Leary RJ, Angenendt P, et al. : An integrated genomic analysis of human glioblastoma multiforme. Science 321 : 1807-1812, 2008

80. Parsons DW, Roy A, Yang Y, Wang T, Scollon S, Bergstrom K, et al. : Diagnostic yield of clinical tumor and germline whole-exome sequencing for children with solid tumors. JAMA Oncol 2 : 616-624, 2016

81. Patil S, Chamberlain RS : Neoplasms associated with germline and somatic NF1 gene mutations. Oncologist 17 : 101-116, 2012

82. Paugh BS, Qu C, Jones C, Liu Z, Adamowicz-Brice M, Zhang J, et al. : Integrated molecular genetic profiling of pediatric high-grade gliomas reveals key differences with the adult disease. J Clin Oncol 28 : 3061 3068, 2010

83. Pollack IF, Finkelstein SD, Woods J, Burnham J, Holmes EJ, Hamilton RL, et al. : Expression of p53 and prognosis in children with malignant gliomas. N Engl J Med 346 : 420-427, 2002

84. Randerson-Moor JA, Harland M, Williams S, Cuthbert-Heavens D, Sheridan E, Aveyard J, et al. : A germline deletion of p14(ARF) but not CDKN2A in a melanoma-neural system tumour syndrome family. Hum Mol Genet $10: 55-62,2001$

85. Ranger A, Szymczak A, Hammond RR, Zelcer S : Pediatric thalamic glioblastoma associated with Ollier disease (multiple enchondromatosis): a rare case of concurrence. J Neurosurg Pediatr 4 : 363-367, 2009

86. Rednam SP, Erez A, Druker H, Janeway KA, Kamihara J, Kohlmann WK, et al. : Von Hippel-Lindau and hereditary pheochromocytoma/paraganglioma syndromes: clinical features, genetics, and surveillance recommendations in childhood. Clin Cancer Res 23 : e68-e75, 2017

87. Reyes D, Prayson R : Glioblastoma in the setting of tuberous sclerosis. J Clin Neurosci 22 : 907-908, 2015

88. Rizvi NA, Hellmann MD, Snyder A, Kvistborg P, Makarov V, Havel JJ, et al. : Cancer immunology. Mutational landscape determines sensitivity to PD-1 blockade in non-small cell lung cancer. Science 348 : 124-128, 2015

89. Rosenfeld A, Listernick R, Charrow J, Goldman S: Neurofibromatosis type 1 and high-grade tumors of the central nervous system. Childs Nerv Syst $26: 663-667,2010$

90. Rosser T, Packer RJ : Intracranial neoplasms in children with neurofibromatosis 1. J Child Neurol 17 : 630-637; discussion 646-651, 2002

91. Santin AD, Bellone S, Buza N, Choi J, Schwartz PE, Schlessinger J, et al. : Regression of chemotherapy-resistant polymerase $\epsilon$ (POLE) ultra-mutated and MSH6 hyper-mutated endometrial tumors with nivolumab. Clin Cancer Res 22 : 5682-5687, 2016

92. Saya S, Killick E, Thomas S, Taylor N, Bancroft EK, Rothwell J, et al. : Baseline results from the UK SIGNIFY study: a whole-body MRI screening study in TP53 mutation carriers and matched controls. Fam Cancer 16 : 433-440, 2017

93. Scheffzek K, Ahmadian MR, Wiesmüller L, Kabsch W, Stege P, Schmitz F, et al. : Structural analysis of the GAP-related domain from neurofibromin and its implications. EMBO J 17 : 4313-4327, 1998

94. Schneider K, Zelley K, Nichols KE, Garber J : Li-Fraumeni syndrome in Adam MP, Ardinger HH, Pagon RA, Wallace SE, Bean LJH, Stephens K, Amemiya A (eds) : GeneReviews ${ }^{\circledR}$. Seattle : University of Washington, 
1993

95. Sharif S, Ferner R, Birch JM, Gillespie JE, Gattamaneni HR, Baser ME, et al. : Second primary tumors in neurofibromatosis 1 patients treated for optic glioma: substantial risks after radiotherapy. J Clin Oncol 24 : 2570-2575, 2006

96. Sherborne AL, Lavergne V, Yu K, Lee L, Davidson PR, Mazor T, et al. : Somatic and germline TP53 alterations in second malignant neoplasms from pediatric cancer survivors. Clin Cancer Res 23 : 1852-1861, 2017

97. Shete S, Lau CC, Houlston RS, Claus EB, Barnholtz-Sloan J, Lai R, et al. : Genome-wide high-density SNP linkage search for glioma susceptibility loci: results from the gliogene consortium. Cancer Res 71 : 7568-7575, 2011

98. Shibahara I, Sonoda Y, Suzuki H, Mayama A, Kanamori M, Saito R, et al. : Glioblastoma in neurofibromatosis 1 patients without IDH1, BRAF V600E, and TERT promoter mutations. Brain Tumor Pathol 1 : 10-18, 2018

99. Shlien A, Campbell BB, de Borja R, Alexandrov LB, Merico D, Wedge D, et al. : Combined hereditary and somatic mutations of replication error repair genes result in rapid onset of ultra-hypermutated cancers. Nat Genet 47 : 257-262, 2015

100. Tabori U, Baskin B, Shago M, Alon N, Taylor MD, Ray PN, et al. : Universal poor survival in children with medulloblastoma harboring somatic TP53 mutations. J Clin Oncol 28 : 1345-1350, 2010

101. Tabori U, Hansford JR, Achatz MI, Kratz CP, Plon SE, Frebourg T, et al. : Clinical management and tumor surveillance recommendations of inherited mismatch repair deficiency in childhood. Clin Cancer Res 23 : e32e37, 2017

102. Tabori U, Laberge AM, Ellezam B, Carret AS : Cancer Predisposition in Children with Brain Tumors : Pediatric Neuro-oncology. New York : Springer New York, 2015, pp69-89

103. Tabori U, Shlien A, Baskin B, Levitt S, Ray P, Alon N, et al. : TP53 alterations determine clinical subgroups and survival of patients with choroid plexus tumors. J Clin Oncol 28 : 1995-2001, 2010

104. Tinat J, Bougeard G, Baert-Desurmont S, Vasseur S, Martin C, Bouvignies E, et al. : 2009 version of the Chompret criteria for Li Fraumeni syndrome. J Clin Oncol 27 : e108-e109; author reply e110, 2009

105. Unger PD, Taff ML, Song S, Schwartz IS : Sudden death in a patient with Von Recklinghausen's neurofibromatosis. Am J Forensic Med Pathol

\section{5 : 175-179, 1984}

106. Uyttebroeck A, Legius E, Brock P, Van de Cassey W, Casaer P, CasteelsVan Daele M : Consecutive glioblastoma and B cell non-Hodgkin's lymphoma in a young child with von Recklinghausen's neurofibromatosis. Med Pediatr Oncol 24 : 46-49, 1995

107. Varan A, Şen H, Aydin B, Yalçın B, Kutluk T, Akyüz C : Neurofibromatosis type 1 and malignancy in childhood. Clin Genet 89 : 341-345, 2016

108. Villani A, Malkin D, Tabori U : Syndromes predisposing to pediatric central nervous system tumors: lessons learned and new promises. Curr Neurol Neurosci Rep 12 : 153-164, 2012

109. Villani A, Shore A, Wasserman JD, Stephens D, Kim RH, Druker H, et al. : Biochemical and imaging surveillance in germline TP53 mutation carriers with Li-Fraumeni syndrome: 11 year follow-up of a prospective observational study. Lancet Oncol 17 : 1295-1305, 2016

110. Wasserman JD, Novokmet A, Eichler-Jonsson C, Ribeiro RC, RodriguezGalindo C, Zambetti GP, et al. : Prevalence and functional consequence of TP53 mutations in pediatric adrenocortical carcinoma: a children's oncology group study. J Clin Oncol 33 : 602-609, 2015

111. Watanabe T, Vital A, Nobusawa S, Kleihues P, Ohgaki H : Selective acquisition of IDH1 R132C mutations in astrocytomas associated with LiFraumeni syndrome. Acta Neuropathol 117 : 653-656, 2009

112. Wimmer K, Etzler I : Constitutional mismatch repair-deficiency syndrome: have we so far seen only the tip of an iceberg? Hum Genet 124 : 105122,2008

113. Wimmer K, Kratz CP, Vasen HF, Caron O, Colas C, Entz-Werle N, et al. : Diagnostic criteria for constitutional mismatch repair deficiency syndrome: suggestions of the European consortium "Care for CMMRD" (C4CMMRD).

J Med Genet 51 : 355-365, 2014

114. Wimmer K, Rosenbaum T, Messiaen L : Connections between constitutional mismatch repair deficiency syndrome and neurofibromatosis type 1. Clin Genet 91 : 507-519, 2017

115. Zhang J, Walsh MF, Wu G, Edmonson MN, Gruber TA, Easton J, et al. : Germline mutations in predisposition genes in pediatric cancer. N Engl J Med 373 : 2336-2346, 2015

116. Zhukova N, Ramaswamy V, Remke M, Pfaff E, Shih DJ, Martin DC, et al. : Subgroup-specific prognostic implications of TP53 mutation in medulloblastoma. J Clin Oncol 31 : 2927-35, 2013 